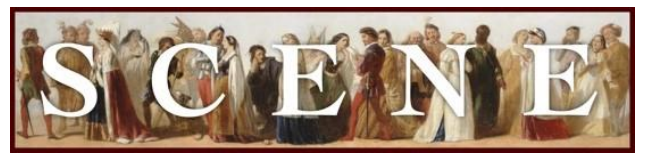

\title{
OPS Fest The Taming of the Shrew
}

\author{
by Elizabeth Tavares. Written on 2017-04-10. Published in 2017 Issue 2.
}

For the production: The Taming of the Shrew (2017, Original Practice Shakespeare Festival at the Mission Theatre). See production details at the end of the review.

"Why should anyone be frightened by a hat?"

\section{- Antoine de Saint-Exupéry, The Little Prince}

For the Original Practice Shakespeare Festival (OPS Fest), the teXt of William Shakespeare's First Folio is a wellspring for improvisational comedy. The troupe employs an actor-oriented original practice, referred to as First Folio technique by practitioners, to render accessible Renaissance theater to Portland and the Pacific Northwest region. The troupe is nearly a decade into their mission of adding two Shakespeare plays into their repertoire each summer until they can rotate the entire canon. In a culturally "white" region that prides itself on progressivism, there are a few plays that pose unique challenges, either in terms of casting, namely Othello, or ethics, such as The Taming of the Shrew. OPS Fest's recent performance of Shrew at the Mission Theatre was a test-run of sorts, designed to consider whether it is an ethically stage-able play in 2017.

Three crucial and unique elements of their performance worked to acknowledge and account for the misogyny and depictions of violence against women in Shrew. It is helpful to note that the troupe doesn't rehearse in the traditional text-oriented blocking sense, but instead gets together for several weekends of playgroup activities, stretching out and developing their improvisational muscle. The day of the performance, each actor is given a scroll with just their part and two iambs-worth of cues. Often, they don't know who is playing whom, and whether they are playing characters as male, female, or non-binary. To help keep the company on-track, a Prompter is incorporated into the action, this time played by company manager Beth Yocam. Typically, the Prompter corrects dropped lines, helps an actor find their cues, encourages audience participation in subtle ways, or occasionally interrupts the action to highlight and make entertaining an otherwise inexplicable oddity in the text. For example, in 1.1 Lucentio (Joel Patrick Durham) says, "For in a quarrel since I came ashore / I kill'd a man, and fear I was descried"; the Prompter interjected to ask, "Why did you kill someone, Lucentio?" The actor then 
must make up a response or backstory, often capitalizing on the space and any physical comedy gags that are beginning to take root in the production. Likewise, Petruchio (Brian Burger) was asked to perform the "wooing dance" he mentions in passing in 1.2 to hilarious effect. In this case, dressed as a referee in a black-and-white uniform, the Prompter could re-direct, halt the action, or otherwise intervene for an audience member if need be. (Such a need never arose.)

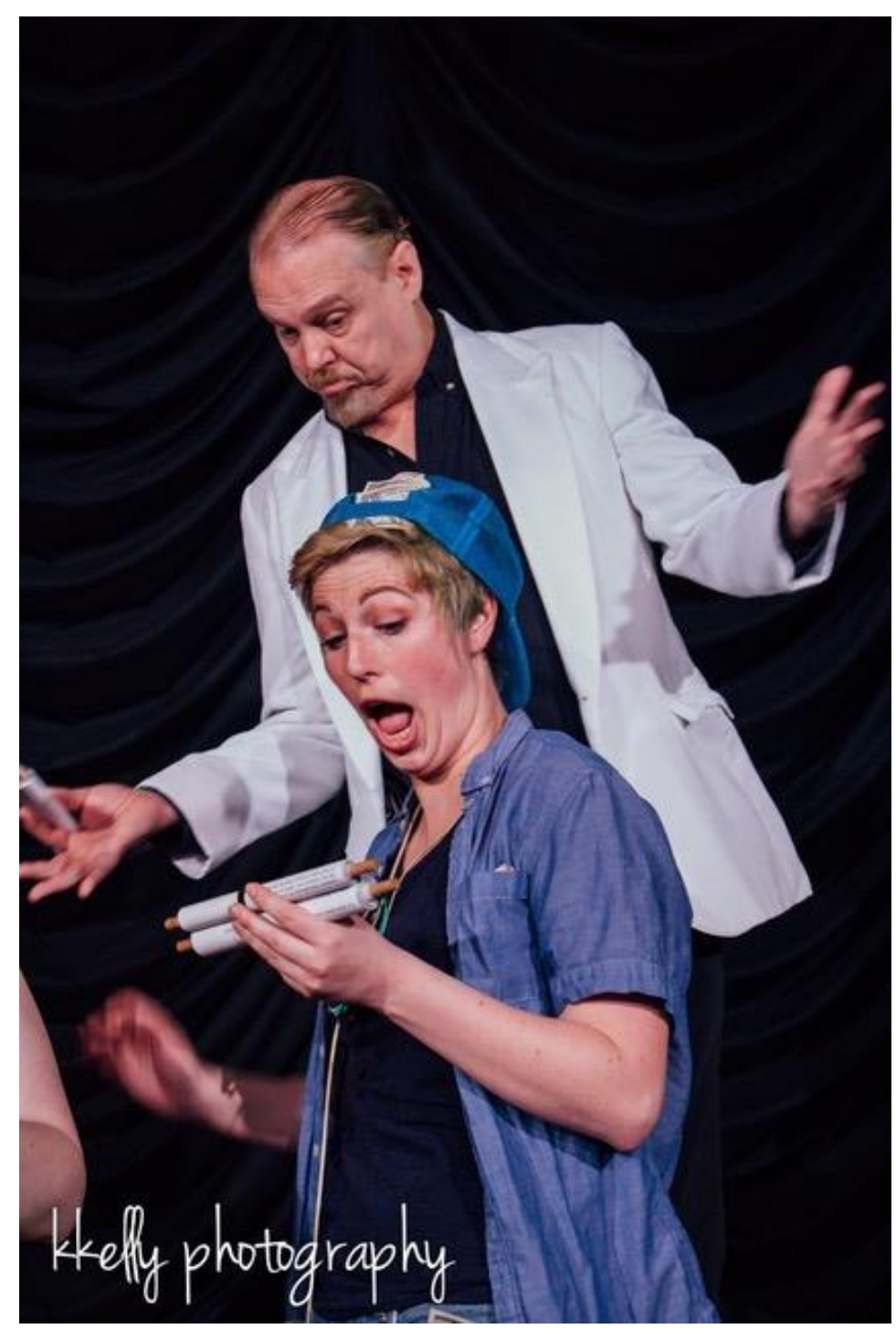

Figure 1: Michael Streeter (Gremio) and Isabella Buckner (Tranio).

Photograph by Kathleen Kelly

Brian Allard, founding artistic director of the troupe, took the part of Christopher Sly, doublydifficult because of the need to manage comic interjections as well as a lack of clear exit or resolution to the framing device of the play. The costume juxtaposition of a loose plaid shirt, worn denim, deep-brown ale in hand, and now-ubiquitous red baseball cap closely associated with the 2016 U.S. presidential elections for Sly, as opposed to tight black jeans, 


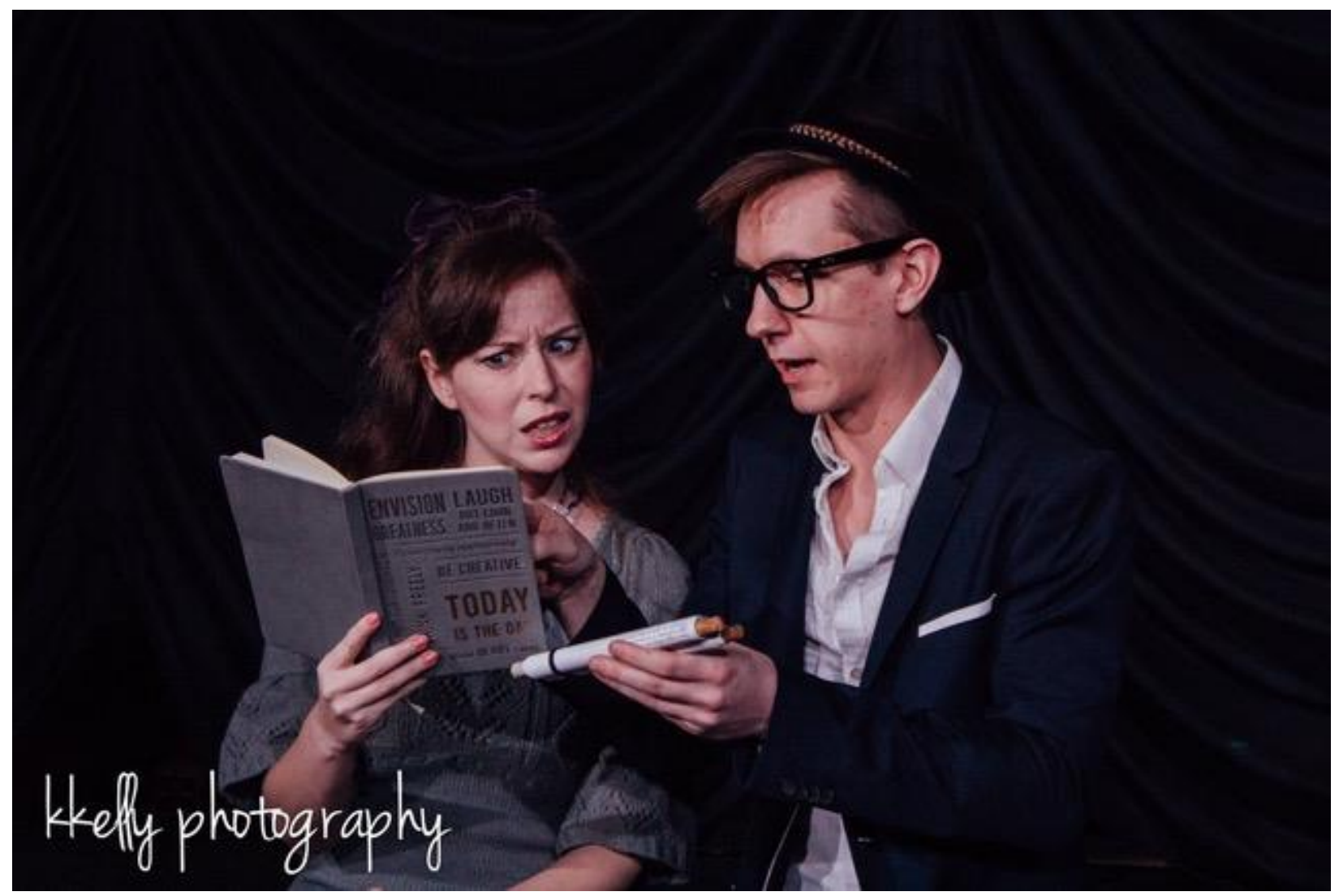

Figure 2: Sarah Jane Fridlich (Bianca) and Jole Patrick Durham (Lucentio). Photograph by Kathleen Kelly.

fitted shirts, and chunky Doc Martins for the lovers, powerfully reflected the contrast between Portland and rural Oregon politics. Much in the news, with Ammon Bundy and his compatriots found not guilty for their martial occupation of the Malheur National Wildlife Refuge, the local political climate added topical immediacy to these visual clues. The production is staged in The Mission Theatre, formerly the Swedish Evangelical Mission Covenant Church before being saved from demolition and retrofitted into an early twentieth-century theater space and brew pub, which is filled with cushioned couches and low tables perfect for its cocktails-for-two clientele. The space itself reflects the tension between west coast foodie culture and regional history. Sly, lolling on one of the couches with the Lord (Alec Lugo) for much of the production, performed his cued interjections as well as ad-libbing a few of his own. For example, in response to Lucentio's enquiry about lodging in act 1, Sly interjects, "You can stay with me, man." When Baptista lamented in act 2, "Was ever gentleman thus griev'd as I?", Sly responds, "I was once." And perhaps the greatest success for the baseball cap allusion was in Tranio's act 5 query, "Have you ever been at Pisa?" with Sly answering, "Immigration is hard!" None of these interjections were sexually explicit or pointed as overtly referencing current U.S. politics. Rather, they all gestured toward systemic inequalities. Tellingly, while the specificity of 
Sly's costume gave playgoers a clear object to despise, his interjections were lightly chuckled at and otherwise ignored.

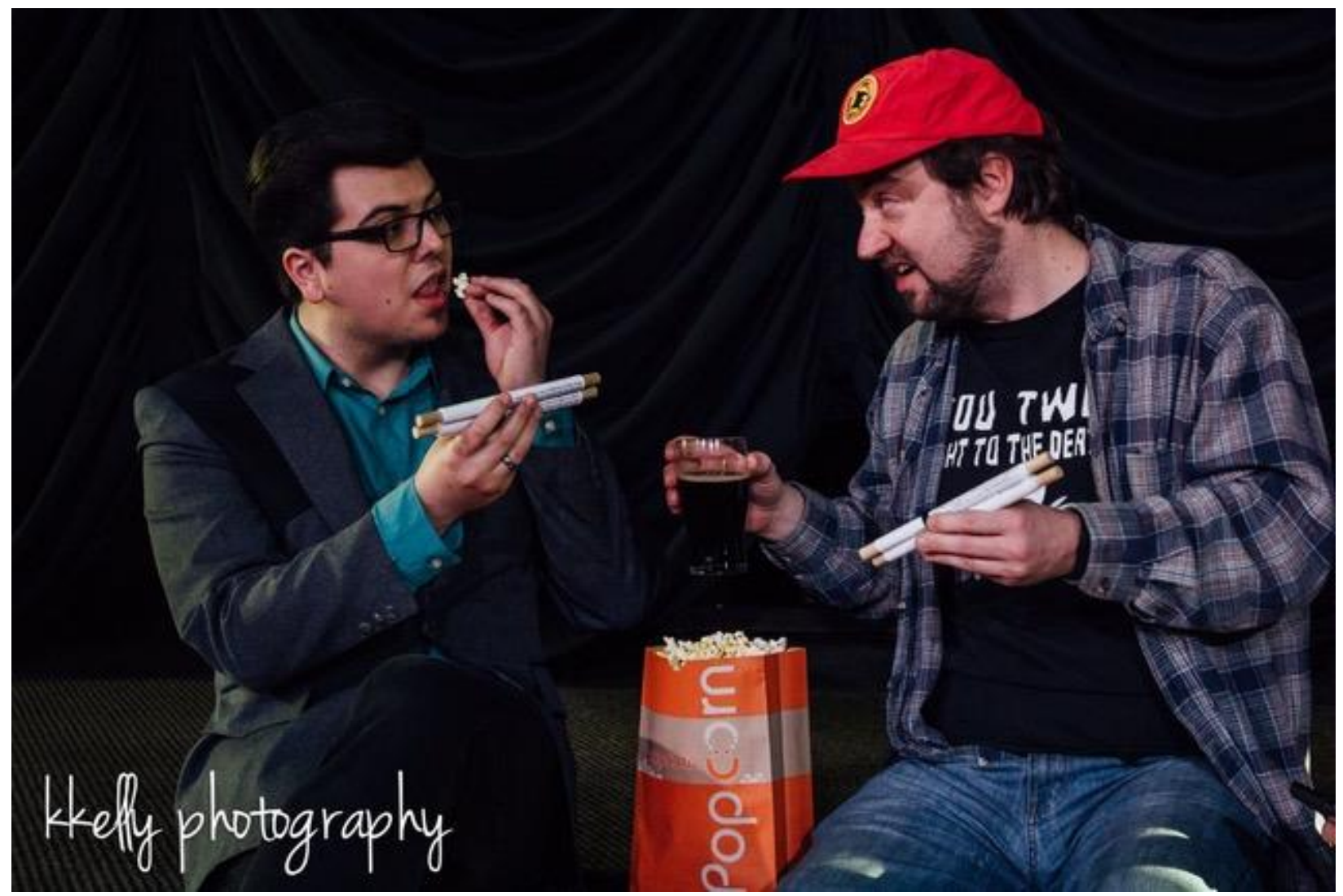

Figure 3: Alec Lugo (Lord) and Brian Allard (Christopher Sly). Photograph by Kathleen Kelly.

The red baseball cap was not the only powerfully allusive prop hat in the production. It is important to note that actors make their own costuming and performance choices largely exclusive of one another, and then bring those pieces together on the day of performance. Allard could not have predicted that Burger would interpret Petruchio's "motley" by coming to the wedding scene in a film-accurate Harry Potter robe. Nor could he have predicted the inspired decision by Shandi Muff, an accomplished costumer in her own right, playing Kate, to come to act five with a bright pink, knitted pussyhat, calling attention to the massive Women's Marches in Portland and Washington, D.C. (now widely considered the largest U.S. protest in history) a few months earlier. While I cannot say her interpretation completely recovers Kate's speech in 5.2, it does make a new reading of it very convincing. To a room full of men, many with military backgrounds, and a widow not on her side, Kate's speech begins, "Fie, fie! unknit that threatening unkind brow." The "unknit" of her speech calls attention to her pink knit hat. We are asked to think about women's rights movements in all their forms-suffrage, equal pay, healthcare and family planning-which frame's Kate in this moment as responding and still resisting to patriarchal structures. To my ears, the rebuke of "Fie! Fie!" and the request to relax a 
furrowed brow sounds like the rhetoric of deescalation that has greeted much 2oth and 21st century activism. Furthermore, imbued with a new quality of subtle, virtuous resistance, Kate's character begins, with the help of the knit hat as a positioning tool, to seem something akin to King Lear's Kent or Othello's Emilia.

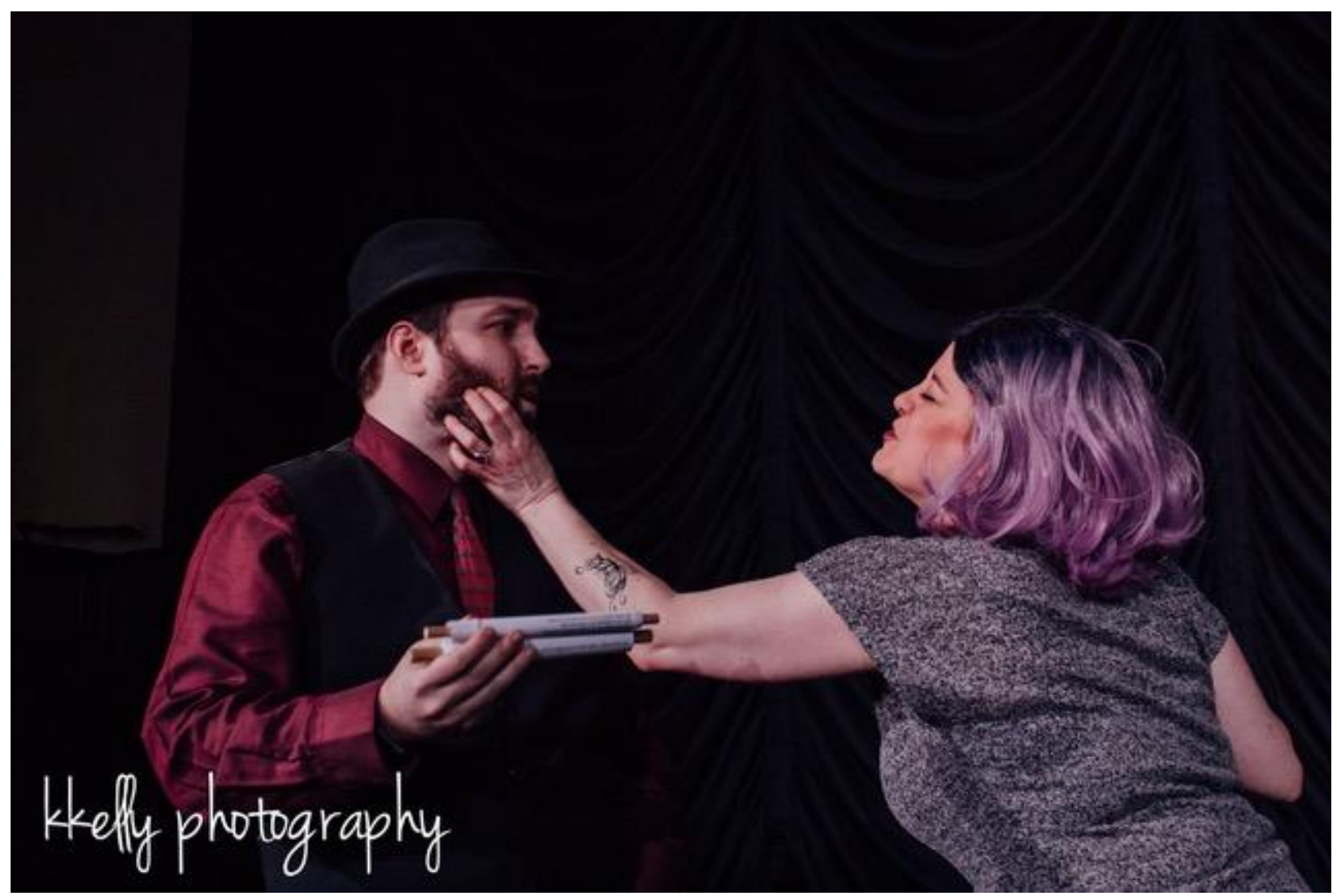

Figure 4: Brian Burger (Petruchio) and Shandi Muff (Kate). Photograph by Kathleen Kelly.

In addition to the Prompter and the careful use of hats, the production was followed with a talkback led by Lauren Saville (a company member and professional therapist), who used expressive arts therapy praxis to organize the playgoers' processing of the play. Having been encouraged to express their displeasure with booing and hissing throughout the performance, the audience of around seventy seemed comfortable to engage with Saville, Allard, and the entire cast who participated in the talk-back. It was interesting to note that the loudest disapproval was not aimed at Sly's interjections or Kate's final speech, but at three sexually-explicit asides made by Gremio (Michael Streeter) and aimed at Bianca. Openly reflecting on this with the audience, the talk-back group slowly realized that, for this production, the misogyny of the play perhaps lay not in individual characters. The male community colludes in its subjection of women to psychological control. The female community likewise fails to support those particularly targeted, such as the motherless Kate and Bianca. If the performance was designed as a test 
run, the result suggested by the audience was, "yes, we do need this Shakespeare play now, pussy-knit and red caps alike."

Elizabeth Tavares is Assistant Professor of Arts and Humanities at Pacific University. Specializing in Shakespeare and Tudor drama, her research foci include playing companies, theater history and performance. Tavares' scholarship and reviews have appeared in or are forthcoming from Shakespeare Bulletin, Shakespeare Studies, The Journal of Dramatic Theory and Criticism, The Journal of the Wooden O Symposium, and Notes \& Queries, among others. She has also contributed to numerous theater blogs, Digital Humanities projects, and edited collections in Television Studies.

\section{Production Details}

\section{General}

Title

Year

Theater Company

Theaters

Start Date

End Date
The Taming of the Shrew 2017

Original Practice Shakespeare Festival

Mission Theater

2017-04-10

2017-04-10

\section{Cast}

\begin{tabular}{|c|c|}
\hline PROMPTER & BETH YOCAM \\
\hline CHRISTOPHER SLY & BRIAN ALLARD \\
\hline LORD & ALEC LUGO \\
\hline LUCENTIO/NICOLAS & JOEL PATRICK DURHAM \\
\hline TRANIO & ISABELLA BUCKNER \\
\hline GREMIO/NATHANIEL & Michael StREETER \\
\hline HOTENTIO & NOAH GOLDENBERG \\
\hline BAPTISTA/CURTIS/TAYLOR & TOM WITHERSPOON \\
\hline KATE & SHANDI MUFF \\
\hline BIANCA/GREGORY & SARAH JANE FRIDLICH \\
\hline PETRUChio & BRIAN BURGER \\
\hline GRUMIO/WIDDOW & JESSICA HIRCHHORN \\
\hline BIONDELLO/PHILLIP & LISSIE LEWIS \\
\hline
\end{tabular}




\section{Creatives}

DIRECTOR

Founding ARTistic Director

MANAGING DiRECTOR

EDUCATION DIRECTOR

COMPANY MANAGER

APPRENTICE DIRECTOR

Musical Director

FIGHT CHOREOGRAPHER

CHOREOGRAPHER

POSTER ART
BRIAN ALLARD

BRIAN ALLARD

SHANDI MUFF

JOEL PATRICK DURHAM

BETH YOCAM

LAUREN SAVILLE

ANDREW BRAY

JOEl PATRICK DURHAM/BRIAN AlLARD

KaIA MaARJA Hillier

MiKe WALlace 